\title{
Study on How to Enhance the Teaching Efficiency of World Outlook and Outlook on Life
}

\author{
Qiu Lin \\ Department of Humanities and Social Sciences, Henan Institute of Engineering, Zhengzhou, 451191, China \\ qiulin4159@163.com
}

\begin{abstract}
To improve the efficiency of teaching world outlook and outlook on life, This paper concluded by the experience summary, investigation method and literature method. Firstly, the educators should reinforce their own education of world outlook and outlook on life; secondly, improve the communications between teachers and students; thirdly, such effective methods as discussion, debate, role play, situational teaching and so forth should be adopted. The implementation of these measures is to help students build up correct outlook on life.
\end{abstract}

Index Terms - world outlook, outlook on life, educators, students

\section{Introduction}

At the turn of Chinese society, people's ideas and thoughts have changed greatly, with some unhealthy ideas and behaviors surfacing and corrupting the teenagers, honesty lost, and pornography, gambling and addiction flaring up again like dying embers. As a result, some students have fallen into evil ways of money worship, hedonism, cynicism, and crimes. Therefore, by the means of class teaching, it is vital to help students acquire proper world outlook and outlook on life, and eliminate the harmful influences on students as quickly as we can. The cultivation of correct world outlook, outlook on life and values is significant for university students. As for the issues, an abundance of achievements have been achieved by sores of professors and scholars from different angles. However, it is acceptable that the significance of outlook education is to be strengthened by its real efficiency, and the problem is to be settled more technically and effectively in the study. As an educator of ideology and politics, how can we help students acquire correct world outlook and outlook on life properly? Some effective measures must be taken, as educators teaching themselves to enhance quality education, strengthening communication between teachers and students, adopting some flexible teaching methods in class. As it follows, I will analyze and reflect on what I have summed up in teaching practices.

\section{It Is Foremost For Educators To Strengthen Their Own Education Of World Outlook And Outlook On Life}

Just as Confucius said, if the ruler is upright, everything will go well even though he does not give orders, and vice versa. As a teacher of ideology and politics, the inside and outside of classrooms are both important for students' education, and the combination can make students accept you. Otherwise, all will be in vain. Ushinski, a Russian educator, said" only personality can influence the formation and development of personality, only personality forms personality." He also said" as to education, all should be based on educators' personality. As education works in real and vivid personality, the personality can not be replaced by whatever rule and whatever clever trick." Yang Xong, who lived in the Xihan Dynasty, said" teaching means setting examples." Be teacher with abundant knowledge, model with lofty virtue. Students model themselves on teachers constantly together with them and learn from them. If teachers' words do not square with deeds, mixed with dull and empty talk, there will be no personal influences, and the students will have psychology of aversion, be resentful and conflict with teachers. While a teacher requires students to deal with people and work realistically, truthfully and dialectically, he treats poor students as he finishes off with one blow; although students are asked to deal with life positively, teachers are negative in class with endless complaints; while students are ordered to be helpful and have courage to do what is right, the teacher is selfish and cowardly; while students are taught to be large-minded, the teacher is very narrow-minded. The teacher with improper world and life outlook can not teach their values properly and make students wholly convinced. Ushinski, who has a democratic work style, said" the influences of teachers' ideology and moral on students are a kind of instructive force that can not be replaced by any text books, moral maxims, punishments and awards. Thus, teachers of ideology and politics must boost up their own qualities, and acquire correct life and world outlook.

\section{Enhance The Communication And Understanding Between Students And Teachers}

At present, university students have many mental and psychological issues, such as psychological imbalance caused by disappointment in love, sense of inferiority and envy caused by poverty, selfishness and narrow-mindedness of only child. Such issues have led to such tragedies as Ma Jia Jiao and Liu Hai Yang, who became prisoners overnight. They are worth the deep reflections of politics and ideology teachers, and meanwhile have set higher standards for political and ideological education. It requires teachers to communicate and understand students to the best of their ability, solve their mental and psychological problems by taking appropriate measures, and thus improve the teaching efficiency.

While some of university students have sorts of shortcomings, they have distinct personalities. Teachers should respect them, sincerely love them, and get along well and equally. The simple and cruel ways of easy scolding, cursing, 
derision, and irony will certainly bring about abnormal psychology, intense relationship between students and teachers and losing popular trust, which affect teaching severely.

The political and ideological teachers make the best of class teaching to enhance communication between students and teachers. As I have talked about " human socialization", any individual can not be separate from groups and society, and thus everyone should create a good environment of existence and development for himself and others. There should be kindness, mutual respect and understanding among people, since they have born independent personality, dignity and equal rights, whether they are beautiful or ugly, poor or rich. Any person has a noble mind, and even though his heart is an unknown and mysterious world for others, he is a beautiful scene. When getting along with others, we can not easily contempt others. Thus, not only have teachers ignite self-respect and love of students who feel humiliated, but also show their own views on human contacts, which make them seem reliable and affectionate. For instance, many students are willing to tell me about their little secrets, like confusions and disappointments in love. I can sincerely help students solve their mental and psychological issues to achieve a better goal for ideological and political education.

\section{Some Ways Of Improving Class Teaching}

To make the class of teaching life and world more efficient, teachers must utilize their own initiatives to make class lively, and focus students' attention and mentality on teaching contents in class. The purpose of political and ideological education is to make students grasp relevant theories, enhance students' moral and personal qualities, help acquire proper outlooks and values, which can be of all kinds to achieve the goal. In teaching ways, it is not " only one road on the Hua Mountain since the ancient times", but "all roads lead to Rome". Every class can be designed in different ways. In teaching practice of ideological and political class, I stick to my own principles, giving full play to students' activity and initiation in all ways, encouraging students to interact, helping them to talk actively and bravely, tapping their potentials of creativity, students being the main body and teachers playing the roles of organizer and host. In the following, I will talk about some of my ways of firing students with initiation and enthusiasm, and leaving them transferring from hating study to loving study.

\section{1) Discussion.}

The subjects relevant to students' life and deeply touching them are assigned for students to talk about, and then several representatives of individual groups make speeches in front of the class, finally comes the teacher's evaluation. Through the discussion, the understandings are deepened and relationship between students and teachers harmonized, thus knowledge is absorbed, which means "be close to your master, follow his way." Discussions are beneficial to interaction between teachers and students and firing students' mental abilities, and meanwhile helpful to improvement of language abilities.

\section{2) Argument.}

Just as the saying goes, the more people argue, the clearer the truth reveals. The topics that can easily confuse and mislead students are discussed in class as disputes to enhance students' cognitive abilities. For instance, as I lectured on " on human social and individual values", I assigned them a topic: what is true beautiful appearance? As is known, many students seek to follow such trends as famous brands, although they are economically poor. One side argued, only if one does something vigorously and is remembered for centuries to come, one is naturally beautiful and such trifles as his or her sanitation, beauty and language elegance can be ignored. The opposed side argued that those who cannot do the ordinary better can do nothing well and there will be no beauty in appearance. With my guidance, both sides collected scores of materials to make cards and defeat the rival. In argument, one side argued that the Red Army could not be sanitary and beautiful when living a hard life in the Long March, but people are impressed by their inner beauty. The opposite side debated against the other by" how can you clean all rooms if one room is never cleaned". Both sides were well documented and stuck to their own versions, had a heated verbal exchange, and finally the class went to climax. The debate excited the students' desire to think and solve problems, enhanced their logical and mental abilities, and meanwhile made the class lively.

\section{3) Role Play.}

It is a kind of teaching method designed by teachers on the basis of text books, which are played by students. It can meet the students' needs to play, make the audience relaxed and adjust one's emotions, to guide all students to join in teaching activities in high spirits, enjoy study and make teaching more efficient. The method not only boosts students' desire to actively participate but also develop their language ability and oral ability.

\section{4) Illustration.}

Give more real and relevant examples in life and the abstract conceptions and theories will be concrete and easy to grasp. For example, when lecturing "the absoluteness of motion and relativity of the static", some growth stories and examples of emotional change were cited. When lecturing "consciousness as reflections of objective materials", I described students' evaluations of teachers as reflections of teachers in their brains.

Besides, some methods like situational teaching and role play are used to good effect. In the teaching process, the foremost is that the teacher acts as an organizer. For instance, in role imitation teaching, the role to be imitated should firstly be assigned and decided, and the character of the role must be analyzed and rehearsed with students. In the process of teaching, the teacher is the host, and one of his main qualities is that he has abundant intelligence to shed light on students, and can control class teaching flexibly. For example, in discussion, the teacher should help prevent the discussion from developing aberrantly. Sometimes, some students shoot the 
bull endlessly, the speeches being too aberrant, so the teacher must properly warn. When the discussion is coming to a deadlock, the teacher may join in to make it lively. At the end of each class, the teacher needs to evaluate each student. In evaluation, praise and encouragement should be dominant to boost the students' confidence and originality. An educator said "the education which never teaches confidence but knowledge is never successful, as knowledge will be out-of- date in time, but confidence will make one's heart young forever."

\section{References:}

[1] Zhong Liang Feng: Educational Psychology. Beijing: People's Education Press,2004. pp. 39-40

[2] Zhong Liang Feng: Educational Psychology. Beijing: People's Education Press, 2004. p.56.

[3] Guo Ming Dai: Pedagogy. Kaifeng: Henan University Press, 1996.p.87. 